\title{
INFLUENCE OF SPACER ON MICROWAVE DETECTION IN MODULATION-DOPED GaAs STRUCTURES
}

\author{
A. Kozič ${ }^{\text {a }}$, V. Petkun ${ }^{\text {a }}$, A. Čerškus ${ }^{\text {a }}$, H. Shtrikmann ${ }^{\text {b }}$, V. Umansky ${ }^{\text {b }}$, J. Gradauskas ${ }^{\text {a }}$, \\ D. Seliuta ${ }^{a}$, A. Sužiedèlis ${ }^{\text {a }}$, J. Kundrotas ${ }^{a}$, and S. Ašmontas ${ }^{\text {a }}$ \\ ${ }^{a}$ Semiconductor Physics Institute, A. Goštauto 11, LT-01108 Vilnius, Lithuania \\ E-mail: as@pfi.lt \\ ${ }^{\mathrm{b}}$ Braun Center for Submicron Research, Weizmann Institute of Science, 76100 Rehovot, Israel
}

Received 5 April 2006

\begin{abstract}
We present the results of experimental investigation of microwave detection at $f=10 \mathrm{GHz}$ frequency using asymmetrically configured diodes fabricated on the base of modulation-doped AlGaAs / GaAs structures with different width of undoped AlGaAs spacer. Polarity of the detected voltage on the microwave diodes with wide spacer corresponded to thermoelectric electromotive force of the same configuration diodes with $n-n^{+}$junction, and it was opposite on the microwave diodes with narrow spacer. Voltage sensitivity of the diodes with narrow spacer was by one order higher than that of the diodes with wide spacer at room temperature, and almost by two orders higher at liquid nitrogen temperature, reaching the value of $175 \mathrm{~V} / \mathrm{W}$. Investigation of photoluminescence spectra of the modulation-doped semiconductor structures revealed effective electron gathering into 2DEG channel from the doped AlGaAs layer of the structure with narrow spacer, while in the case of wide spacer a part of charge carriers remained in the doped AlGaAs layer. The effective electron gathering into the 2DEG channel created a situation when an interchange between $n^{+}$and $n$ regions of the planar diode occured: the configured 2DEG channel then could be treated as the $n^{+}$region, while the alloyed metallic contacts were as $n$ region of the semiconductor $n-n^{+}$structure. This explains opposite polarities of the detected voltage on the diodes with narrow and wide spacer.
\end{abstract}

Keywords: selectively doped structures, microwaves, detectors

PACS: 73.23.-b, 07.57.Kp

\section{Introduction}

Striking achievements in the field of semiconductor materials engineering suggest new application possibilities of synthetic semiconductor structures. Huge increase of electron mobility in two dimensional (2D) modulation-doped semiconductor structures at cryogenic temperatures [1] enables essential improvement of parameters not only of the traditional high speed devices such as field effect transistors (FETs) and high electron mobility transistors (HEMTs) but also, sometimes, in new unsuspected applications. As an example of such application the detectors of electromagnetic radiation with the operation based on carrier heating effects in strong electric fields could be mentioned. Asymmetrically shaped semiconductor mesa structures on the base of epitaxial $n$-Si structures with $n-n^{+}$ junction have demonstrated their ability to detect microwave radiation in millimetre wavelength range [2]. The asymmetrically shaped $n^{+}-n$-GaAs planar diodes revealed detection properties in wide frequency range: from microwaves up to infrared radiation [3]. The main shortcoming of the hot carrier microwave diodes is their poor voltage sensitivity. Reduction of the "neck" dimensions of the asymmetrically shaped semiconductor structure down to submicrometric scale [4] as well as use of 2D electron gas (2DEG) structures [5] increased substantially the voltage sensitivity of such microwave diodes, particularly at liquid nitrogen temperature. Quality of the 2DEG layer determines the detective properties of the asymmetrically shaped microwave diodes. It was shown that there exists an optimal width of the undoped $i$-AlGaAs spacer separating the doped $n^{+}$-AlGaAs layer from $i$-GaAs region where the 2DEG is formed [6]. Therefore, in this paper we investigate the detection of microwave radiation using the diodes on the base of modulation-doped AlGaAs / GaAs structures with different width of undoped AlGaAs spacer. 


\begin{tabular}{|c|}
\hline$i-\mathrm{GaAs}, 10 \mathrm{~nm}$ \\
\hline$n^{+}-\mathrm{Al}_{0.3} \mathrm{Ga}_{0.7} \mathrm{As}, \mathrm{N}_{\mathrm{d}}{ }^{+}=4 \cdot 10^{17} \mathrm{~cm}^{-3}, 70 \mathrm{~nm}$ \\
\hline$i-\mathrm{Al}_{0.3} \mathrm{Ga}_{0.7} \mathrm{As}, 7.5 \mathrm{~nm}$ \\
\hline$i-\mathrm{GaAs}, 500 \mathrm{~nm}$ \\
\hline $\mathrm{SI}-\mathrm{GaAs}, 400 \mu \mathrm{m}$ \\
\hline
\end{tabular}

(a)

\begin{tabular}{|c|}
\hline$i-\mathrm{GaAs}, 20 \mathrm{~nm}$ \\
\hline$n^{+}-\mathrm{Al}_{0.25} \mathrm{Ga}_{0.75} \mathrm{As}, \mathrm{N}_{\mathrm{d}}{ }^{+}=10^{18} \mathrm{~cm}^{-3}, 80 \mathrm{~nm}$ \\
\hline$i-\mathrm{Al}_{0.25} \mathrm{Ga} \mathrm{a}_{0.75} \mathrm{As}, 45 \mathrm{~nm}$ \\
\hline$i-\mathrm{GaAs}, 1 \mu \mathrm{m}$ \\
\hline $\mathrm{SI}-\mathrm{GaAs}, 400 \mu \mathrm{m}$ \\
\hline
\end{tabular}

(b)

Fig. 1. Cross-sections of modulation-doped GaAs / AlGaAs heterojunctions with different spacer width (a) $d_{i}=75 \AA$ and (b) $d_{i}=$ $450 \AA$.

\section{Samples}

Modulation-doped AlGaAs/GaAs heterostructures were grown by molecular beam epitaxy (MBE) technique on semi-insulating GaAs substrate with different spacer width. Cross-sections of the structures are depicted schematically in Fig. 1. Residual impurities from substrate are trapped by a 30 period superlattice buffer that is embedded between the substrate and $i$-GaAs buffer layer (the superlattices are not shown in the picture). Hall measurements revealed the sheet electron density to be $6.2 \cdot 10^{11} \mathrm{~cm}^{-2}$ for the structure with $d_{i}=75 \AA$ and $1.4 \cdot 10^{12} \mathrm{~cm}^{-2}$ for the structure with a wider spacer $\left(d_{i}=450 \AA\right)$ at room temperature. At liquid nitrogen temperature the electron density slightly decreased $\left(3.9 \cdot 10^{11} \mathrm{~cm}^{-2}\right)$ in the case of the structure with the narrow spacer (NS), while in case of the structure with the wider spacer (WS) more significant reduction of the electron sheet concentration

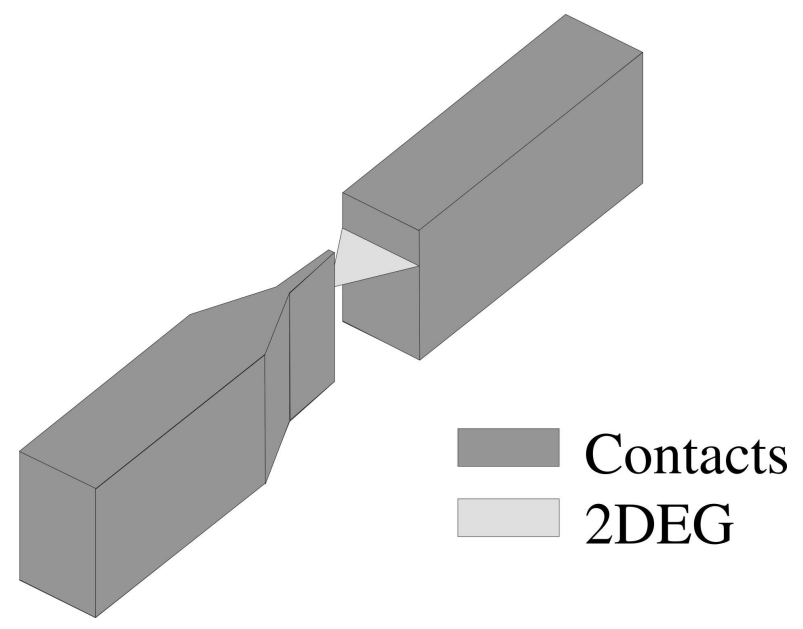

Fig. 2. Schematic view of the microwave diode with triangularly shaped 2DEG layer.

$\left(1.6 \cdot 10^{11} \mathrm{~cm}^{-2}\right)$ was observed. Electron mobility increased with cooling from room down to liquid nitrogen temperature for the structure with NS $(\mu(300 \mathrm{~K})=$ $4800 \mathrm{~cm}^{2} \mathrm{~V}^{-1} \mathrm{~s}^{-1}$ and $\left.\mu(77 \mathrm{~K})=52000 \mathrm{~cm}^{2} \mathrm{~V}^{-1} \mathrm{~s}^{-1}\right)$ as well as for the structure with the WS $(\mu(300 \mathrm{~K})=$ $2400 \mathrm{~cm}^{2} \mathrm{~V}^{-1} \mathrm{~s}^{-1}$ and $\left.\mu(77 \mathrm{~K})=66000 \mathrm{~cm}^{2} \mathrm{~V}^{-1} \mathrm{~s}^{-1}\right)$.

Asymmetrical bow-tie-like shapes of the 2DEG layer were formed by wet chemical etching of mesa structures. The etching was carried out slightly deeper than the inlaying doped $n^{+}-\mathrm{Al}_{x} \mathrm{Ga}_{1-x}$ As layer. The width of the narrowest part, or the neck, of the constricted structure, $d$, was taken from 1 to $3 \mu \mathrm{m}$. Metallic contacts were fabricated by thermal evaporation of $\mathrm{Ni} / \mathrm{Au} / \mathrm{Ge} / \mathrm{Ni} / \mathrm{Au}=10 \mathrm{~nm} / 200 \mathrm{~nm} / 100 \mathrm{~nm} /$ $70 \mathrm{~nm} / 200 \mathrm{~nm}$ layers through photoresistant mask in $3 \cdot 10^{-6}$ Torr vacuum. After rapid annealing at $430^{\circ} \mathrm{C}$ for 40 seconds in forming gas atmosphere, the pattern of ohmic contacts was formed by lift-off technique. The quality of ohmic contacts was controlled by transmission line method. Schematic view of the planar microwave diode is shown in Fig. 2. Actually, it is composed of triangularly shaped 2DEG sheet that is embedded between two massive alloyed metallic contacts.

Photoluminescence (PL) experiments were performed under illumination of Ar ion laser (quantum energy about $2.5 \mathrm{eV}$ ). The excitation intensity was varied from 0.2 up to $30 \mathrm{~W} / \mathrm{cm}^{2}$. The PL was registered by a cooled photomultiplier operating in photon counting regime. Microwave detection was investigated under the radiation of pulse-modulated magnetron generator operating at $f=10 \mathrm{GHz}$ frequency. The samples were mounted into respective rectangular waveguides, and the induced voltage was measured over the ends of the sample. 


\section{Experimental results}

The electrical resistance of the samples was measured in DC regime. The experimental values of electrical resistance of the WS microwave diodes corresponded to the values calculated from geometry of the semiconductor structures both at room and liquid nitrogen temperatures. The measured values of the resistance of the NS microwave diodes were higher than would follow from geometry of the samples. Measurements indicated low values of the contact resistivity: $\rho_{\mathrm{c}}=(0.5-1.0) \Omega \mathrm{mm}$ for the WS samples and $\rho_{\mathrm{c}}=$ $(0.1-0.5) \Omega \mathrm{mm}$ for the NS diodes. The current-voltage characteristics of the samples were linear for both types of the microwave diodes at room and liquid nitrogen temperature (see Fig. 3). These experimental findings let us implicate the depletion of the micron sized neck of the 2DEG layer in the electrical resistance increase of the samples with narrow spacer.

Photoluminescence spectra of the modulation-doped GaAs / AlGaAs structures at $T=80 \mathrm{~K}$ and $T=300 \mathrm{~K}$ for both kinds of the microwave diodes with narrow and wide spacer are presented in Fig. 4(a,b), respectively. Two groups of peaks can be distinguished in the spectrum of the WS structure: the first group of the PL lines is located between 1.7 and $1.9 \mathrm{eV}$, and we at-

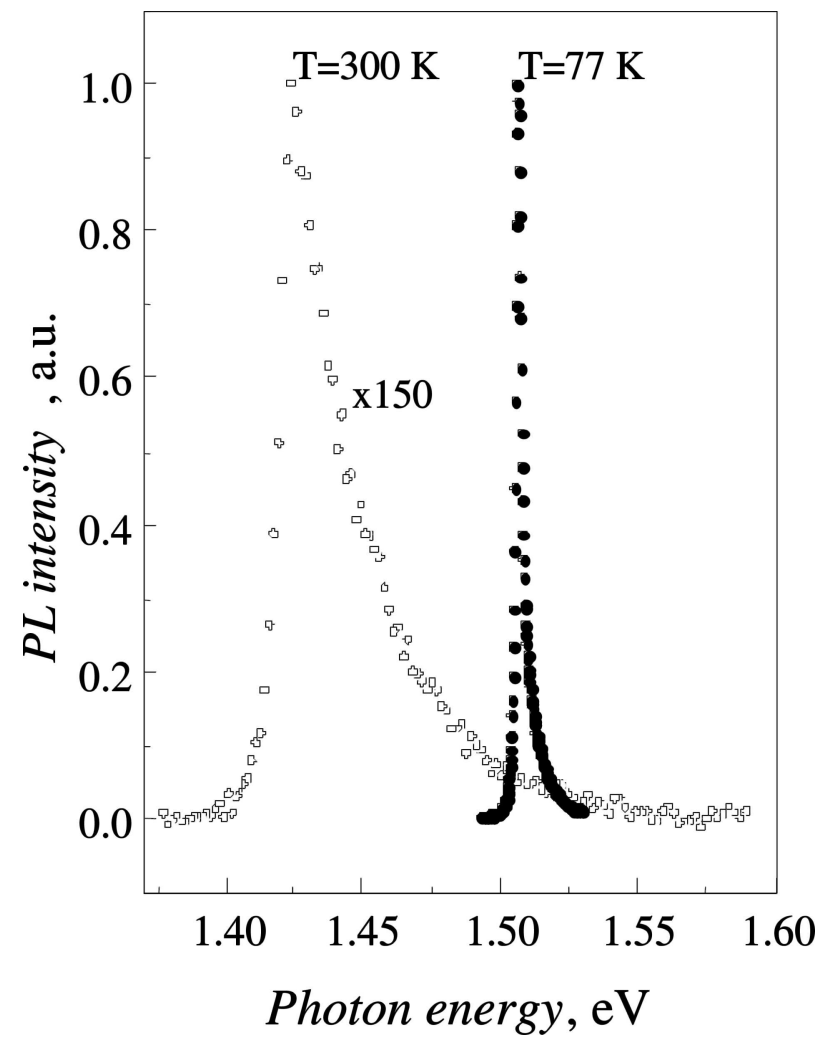

(a)

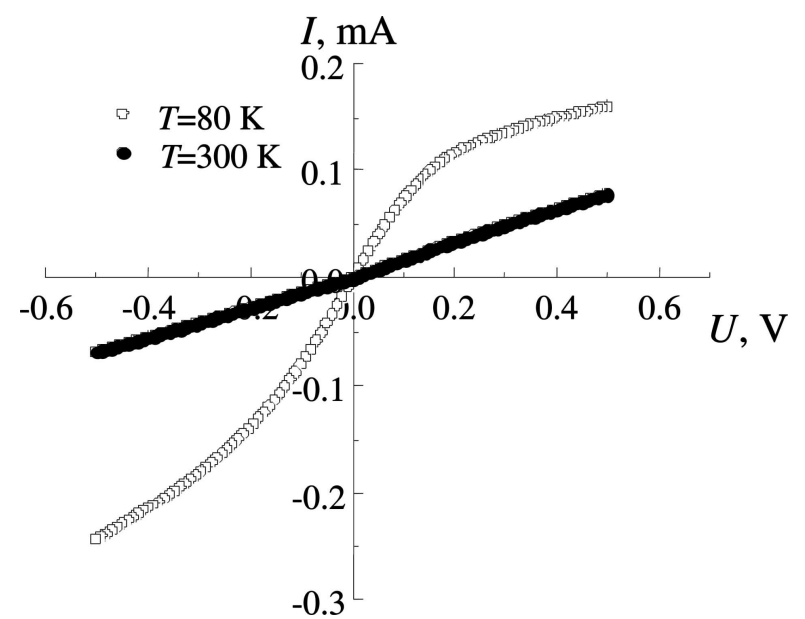

Fig. 3. $I-V$ characteristics of the microwave diodes with narrow spacer measured in DC regime at room and liquid nitrogen temperatures.

tribute it to the recombination of electron-hole pairs in the $\mathrm{A}_{0.25} \mathrm{Ga}_{0.75}$ As layer. Weak intensity of this peak shows that the major part of the photogenerated carriers leave this layer and recombine in GaAs thus emitting light quanta of lower energy. The second group of the PL lines within energies of (1.4-1.52) eV exhibits much stronger intensity, and their energetic position is very close to the excitonic one in GaAs layer where the

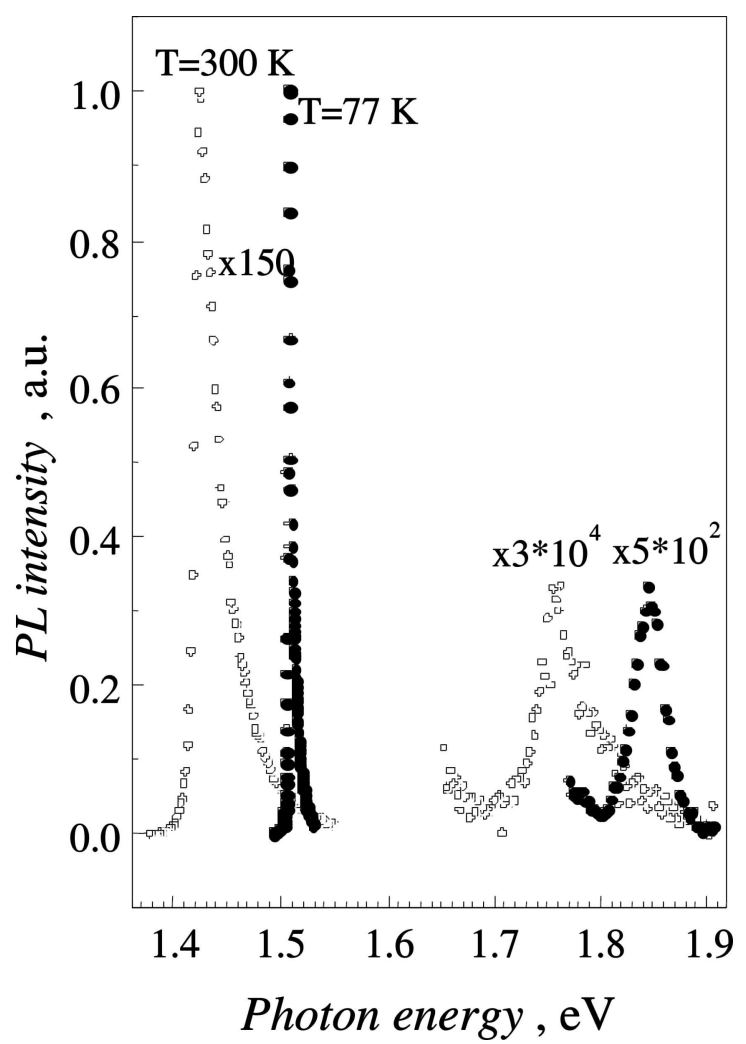

(b)

Fig. 4. Photoluminescence spectra of the modulation-doped GaAs / AlGaAs structures with (a) narrow and (b) wide spacer. 


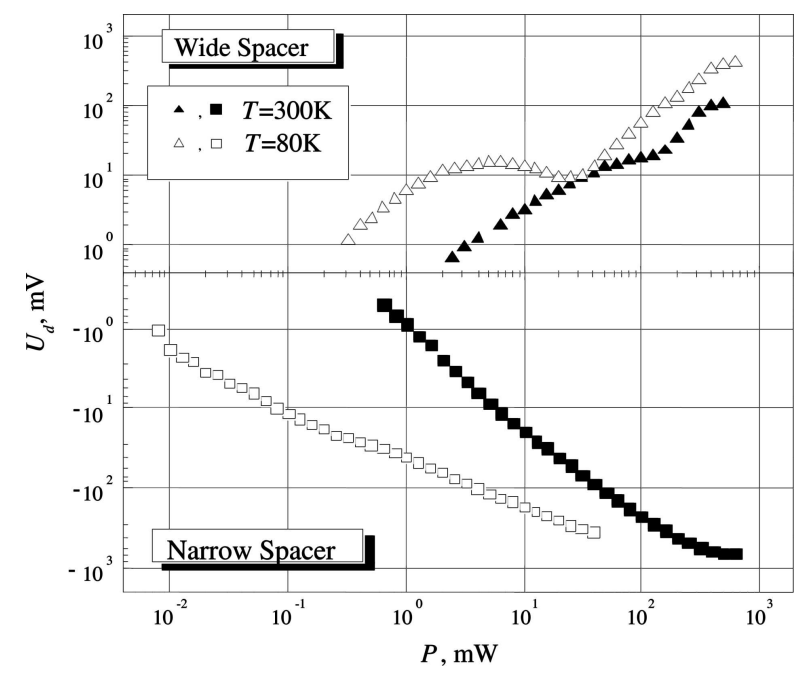

Fig. 5. Voltage-power characteristics of microwave diodes with narrow (square points) and wide (triangle points) spacer measured at room (dark points) and liquid nitrogen (open points) temperatures.

2DEG channel is located. Only this group of the PL peaks can be seen in the spectrum of the NS structure. In this case the absence of the PL lines in the vicinity of 1.7-1.9 eV implies total exhaustion of electrons in the $\mathrm{Al}_{0.3} \mathrm{Ga}_{0.7} \mathrm{As}$ layer and their effective collection in the 2DEG channel.

Polarity of the detected voltage on the WS microwave diode corresponded to the polarity of thermoelectric electromotive force of hot carriers for this configuration of the asymmetrically shaped microwave diode. Dependences of the detected voltage on microwave power are presented in Fig. 5. Linear voltagepower characteristic was observed at low microwave power level, while nonmonotonic character of the dependence occured at higher microwave power. We relate it with carrier intervalley scattering processes occurring in multi-valley semiconductors. Voltage sensitivity of the WS microwave diodes in low microwave power region was $0.3 \mathrm{~V} / \mathrm{W}$ at room temperature and $5.5 \mathrm{~V} / \mathrm{W}$ at liquid nitrogen temperature. Polarity of the detected voltage of the NS microwave diodes was opposite to the detected voltage of the WS diodes. It should be noted that the polarities of the detected voltage of both types of the diodes corresponded to the sign of asymmetry of the $I-V$ characteristics measured in DC regime. Linear dependence of the voltage-power characteristics of the both kinds of diodes was observed up to $100 \mathrm{~mW}$ power at room temperature. However, the voltage sensitivity was almost by one order higher in the case of the NS diodes. At liquid nitrogen temperature the dynamic range of the NS microwave diodes was limited by $100 \mu \mathrm{W}$ of microwave power, how- ever, high value of voltage sensitivity was observed for this type of diodes: $175 \mathrm{~V} / \mathrm{W}$ was the highest voltage sensitivity ever achieved for the planar asymmetrically shaped microwave diodes with operation based on carrier heating phenomena in semiconductors. We explain the opposite polarity of voltage detected on the microwave NS diodes by interchange of $n$ and $n^{+}$regions of the diode: the 2DEG channel acts as $n^{+}$region due to effective collection of electrons from doped AlGaAs layer, and the region of the sample with the alloyed metal is then treated as $n$ region.

\section{Conclusions}

Experimental investigation of detection properties of asymmetrically shaped modulation-doped GaAs / AlGaAs structures with different spacer width lets us to conclude as follows:

- Polarity of the voltage detected on the microwave diodes with wide spacer corresponds to the polarity of the thermoelectric electromotive force of such configuration of $n-n^{+}$junction, and it is opposite to the voltage polarity on the diodes with narrow spacer.

- The voltage sensitivity of the microwave diodes with narrow spacer is by one order higher than that of the diodes with wide spacer at room temperature, and it is almost by two orders higher at liquid nitrogen temperature.

- Investigation of photoluminescence spectra of the modulation-doped semiconductor structures revealed effective electron gathering into $2 \mathrm{DEG}$ channel from the doped AlGaAs layer of the structure with narrow spacer, while in case of wide spacer a part of charge carriers remained in the doped AlGaAs layer.

- Effective electron gathering into 2DEG channel creates situation when an interchange between $n^{+}$and $n$ regions of the planar diode occurs: the configured 2DEG channel can be treated as the $n^{+}$region, while the alloyed metallic contacts are as $n$ region of the semiconductor structure. This consideration explains opposite polarities of the voltages detected on the microwave diodes with narrow and wide spacer.

\section{Acknowledgements}

This work was partially supported by the NATO Science for Peace Programme under the project 
No. 978030 and the Lithuanian State Science and Studies Foundation under the projects Nos. B-03005 and V-05046.

Samples were fabricated at Braun Submicron Research Center under the contract No. RITA-2003506095 .

\section{References}

[1] V. Umansky, R. de-Picciotto, and M. Heiblum, Extremely high-mobility two dimensional electron gas: Evaluation of scattering mechanisms, Appl. Phys. Lett. 71, 683-685 (1997).

[2] S. Ašmontas and A. Sužiedèlis, New microwave detector, Int. J. Infrared Millimeter Waves 15, 525-538 (1994).
[3] A. Sužiedèlis, J. Gradauskas, S. Ašmontas, G. Valušis, and H.G. Roskos, Giga- and terahertz frequency band detector based on an asymmetricallynecked $n-n^{+}$-GaAs planar structure, J. Appl. Phys. 93, 3034-3038 (2003).

[4] S. Ašmontas, J. Gradauskas, A. Kozič, H. Shtrikmann, and A. Sužiedèlis, Submicrometric heavily doped $n$-GaAs structures for microwave detection, Acta Phys. Pol. A 107, 147-150 (2005).

[5] A. Sužiedèlis, A. Kozič, V. Petkun, A. Čerškus, H. Shtrikmann, J. Gradauskas, J. Kundrotas, and S. Ašmontas, Properties of constricted 2DEG/metal structures in microwave electric fields, Opt. Appl. 35, 465470 (2005).

[6] T.J. Drumond, H. Morkoç, and A.Y. Cho, Dependence of electron mobility on spatial separation of electrons and donors in $\mathrm{Al}_{x} \mathrm{Ga}_{1-x} \mathrm{As} / \mathrm{GaAs}$ heterostructures, J. Appl. Phys. 52, 1380-1386 (1981).

\title{
PRIEMAIŠOMIS MODULIUOTU GaAS DARINIŲ SKIRIAMOJO SLUOKSNIO ITAKA MIKROBANGU DETEKCIJAI
}

\author{
A. Kozič ${ }^{a}$, V. Petkun ${ }^{\text {a }}$, A. Čerškus ${ }^{\text {a }}$, H. Shtrikmann ${ }^{\text {b }}$, V. Umansky ${ }^{\text {b }}$ J. Gradauskas ${ }^{\text {a }}$, D. Seliuta ${ }^{\text {a }}$, \\ A. Sužiedèlis ${ }^{a}$, J. Kundrotas ${ }^{a}$, S. Ašmontas ${ }^{\text {a }}$ \\ ${ }^{a}$ Puslaidininkiu fizikos institutas, Vilnius, Lietuva \\ ${ }^{\mathrm{b}}$ Weizmann mokslo institutas, Rehovotas, Izraelis
}

\section{Santrauka}

Pateikiami mikrobangų detekcijos eksperimentinių tyrimų duomenys esant $f=10 \mathrm{GHz}$ dažniui, panaudojant nesimetriškai susiaurintus priemaišomis moduliuotus $\mathrm{AlGaAs} / \mathrm{GaAs}$ darinius su skirtingo pločio skiriamuoju sluoksniu. Detektuotos įtampos poliškumas dariniuose su platesniu skiriamuoju sluoksniu atitiko karštujų krūvininkų šiluminès elektrovaros jègos poliškumą tokios konfigūracijos $n-n^{+}$sandūrai ir buvo priešingas darinio su siauru skiriamuoju sluoksniu detektuotos įtampos poliškumui. Dariniu su siauru skiriamuoju sluoksniu voltvatinis jautris buvo eile didesnis kambario temperatūroje ir beveik dviem eilèmis didesnis skysto azoto temperatūroje ir siekè $175 \mathrm{~V} / \mathrm{W}$. Fotoliuminescencijos tyrimai kambario ir skysto azoto temperatūroje parodè, jog dariniuose su platesniu skiriamuoju sluoksniu dalis krūvininkų lieka priemaišomis papildytame sluoksnyje, o su siauresniu - visi krūvininkai yra efektyviai surenkami potencialiniame elektroninių dujų dvimačiame kanale. Efektyvus elektronų surinkimas i dvimati elektroninių dujų kanalą sukuria situaciją, kai nesimetriškai susiaurinto priemaišomis moduliuoto darinio $n^{+}$ir $n$ sritys susikeičia vietomis, dèl to pasikeičia ir detektuotos ittampos poliškumas. 